\title{
PERAN PENTING PEREMPUAN DALAM GEREJA DI DALAM ALKITAB
}

\section{MELIANUS}

2020196656

\section{G TEOLOGI}

\section{PENGANTAR FILSAFAT}

\section{INSTITUT AGAMA KRISTEN NEGERI TORAJA}

\section{elimelianus96@gmail.com}

\begin{abstract}
The value of a man and a woman is equal in the eyes of God. "There is neither Jew nor Greek, there is neither slave nor free, there is neither male nor female, for you are all one in Christ Jesus." Every human being, regardless of his nationality, class, or gender, is the same. The land under the cross is on the same level - women are as important as men. This is very clear in the life and ministry of Jesus and the apostles. For example, Jesus taught women directly, and was also served by them." While Jesus and His disciples were on their way, He came to a village. A woman named Martha received Him into her home." She was also financially supported by women, and women were also among the first to accept the gospel. A Christian woman should play a role in ministry in the church. Their ministry in the church is also described in the Bible. There is so much they can emulate in the Bible.
\end{abstract}

Key Words: Role, Women,Bible, Church

Abstrak : Nilai seorang pria dan seorang wanita adalah sama di mata Tuhan. "Dalam hal ini tidak ada orang Yahudi atau orang Yunani, tidak ada hamba atau orang merdeka, tidak ada laki-laki atau perempuan, karena kamu semua adalah satu di dalam Kristus Yesus." Setiap manusia, terlepas dari kewarganegaraannya, kelas, atau jenis kelaminnya, adalah sama. Tanah yang berada di bawah kayu salib berada pada tingkat yang sama - wanita sama pentingnya seperti pria. Hal ini sangat jelas dalam kehidupan dan pelayanan Yesus beserta para rasul. Misalnya, Yesus mengajar perempuan secara langsung, dan juga di layani oleh mereka."Ketika Yesus dan murid-murid-Nya dalam perjalanan, tibalah Ia di sebuah kampung. Seorang perempuan yang bernama Marta menerima Dia di rumahnya.” Ia juga didukung secara finansial oleh perempuan, dan perempuan juga termasuk di antara yang 
pertama menerima Injil.seorang perempuan Kristen harusnya berperan dalam pelayanan di gereja. Pelayanan mereka dalam gereja juga di jelaskan di dalam Alkitab. Begitu banyak yang bisa mereka teladani dalam alkitab.

Kata Kunci : Peran, Perempuan, alkitab, gereja

\section{A. Pendahuluan}

Untuk memahami lebih baik tentang keterbatasan perempuan dalam pelayanan, kita perlu memperjelas apa arti kata "mengajar" sebenarnya. Pertama, tentu saja hal ini berbicara tentang hal-hal spiritual di dalam gereja. Ayat/surat itu sendiri merupakan gambaran nyata yang memberikan petunjuk bagi gereja dan perilaku apa yang sesuai di dalamnya. ${ }^{1}$ Oleh sebab itu, ayat ini tidak menghalangi perempuan dari pekerjaan yang memberikan instruksi atau memerintah atas laki-laki di luar struktur gereja. Namun mengingat penggunaanya dalam seluruh Alkitab, kata mengajar adalah "untuk memberikan penyebaran akan ajaran Yesus kristus secara hati-hati dan pernyataan yang berkuasa tentang kehendak Allah bagi orang yang percaya didalam terang ajaran tersebut." Itulah sebabnya, menurut Paulus, wanita tidak menggunakan kepemimpian keagamaan atas laki-laki. Hal ini tidak terbatas atas hubungan antara suami dan istri, melainkan mencakup semua hubungan priawanita di dalam gereja.

Pokok pikiran ini juga muncul dalam 1 Korintus 14: 34, 35 "Sama seperti dalam semua Jemaat orang-orang kudus, perempuan-perempuan harus berdiam diri dalam pertemuan-pertemuan Jemaat. Sebab mereka tidak diperbolehkan untuk berbicara. Mereka harus menundukkan diri,seperti yang dikatakan juga oleh hukum Taurat. Jika mereka ingin mengetahui sesuatu, baiklah mereka menanyakannya kepada suaminya di rumah. Sebab tidak sopan bagi perempuan untuk berbicara dalam pertemuan Jemaat". Dalam ayat ini, Paulus juga menceritakan wanita di Korintus untuk belajar dengan tenang. Banyak yang memperdebatkan bahwa Paulus membatasi perempuan untuk mengajar laki-laki, dan hal tersebut didasarkan sepenuhnya oleh tradisi budaya yang tidak relevan pada zaman ini. Namun,

1. ${ }^{1}$ Amazing Facts Indonesia, "Peran Yang Tuhan Berikan Bagi Perempuan Dalam Pelayanan," https://amazingfacts.id/peran-tuhan-berikan-bagi-perempuan-pelayanan/ (31 Agustus 2016). 
meskipun penting untuk memahami latar belakang sejarah dan budaya dari setiap ajaran Alkitab, Paulus tidak membiarkan kita mengabaikan nasehat ini karna hal tersebut. Setelah memberikan larangan, Paulus memberikan alasan yang kekal untuk itu. "Karena Adam yang pertama dijadikan, kemudian barulah Hawa".

Ayat ini menyatakan bahwa dasar ajaran Paulus merujuk secara langsung kepada penciptaan. Ia secara tegas menyatakan bahwa pria dan wanita diciptakan berbeda dan memiliki peran yang berbeda, bahkan dalam kondisi sebelum kejatuhan manusia. Oleh sebab itu, tidak ada ruang untuk mengatakan bahwa ajaran ini adalah hanya ajaran untuk orang-orang Efesus di waktu dan tempat mereka sewaktu di dunia. Kenyataannya, Paulus sering menuliskan tentang peran dan perbedaan peran antara laki-laki dan perempuan. Misalnya, dalam Efesus 5 dan 6, ia meminta perempuan untuk tunduk kepada suami mereka dan pelayan untuk tunduk kepada tuan mereka. Tentu saja nasehat ini dilanjutkan Paulus dengan membicarakan tentang "manusia baru" di dalam Kristus (Efesus 4:23, 24). Manusia baru adalah manusia yang sudah dirubah sebagai orang yang mengerti pola ciptaan dan dapat hidup dengan kepatuhan terhadap Tuhan. Jadi Paulus tidak pernah menghapuskan tugas laki-laki dan perempuan. Tidak. Ia menjelaskan bahwa Kristus telah menghapuskan

semua perbedaan yang berhubungan dengan nilai rohani: Masing-masing kita dibenarkan oleh iman dan sama-sama diberikan hak untuk menjadi anak-anak Allah.

\section{B. Tujuan}

Jurnal ini bertujuan untuk menjelaskan mengenai peran perempuan di dalam gereja dalam alkitab.

\section{Manfaat}

Setelah kita mengerti dan memahami mengenai peran perempuan dalam alkitab, sangat diharapkan kita semua boleh mengerti mengenai bagaimana peran yang sebenarnya dari seorang perempuan dalam alkitab. Inilah manfaat jurnal ini ditulis, yaitu memberikan pemahaman kepada masing-masing orang tentang bagaimana sebenarnya peran seorang perempuan terutama yang dibahas dalam alkitab.

\section{Pembahasan}


Beberapa orang menyarankan bahwa karena pada umumnya jumlah perempuan lebih banyak daripada laki-laki di dalam gereja, maka peran kepemimpinan harus diberikan sesuai dengan jumlah terbanyak. Bila menggunakan alasan ini, maka anak-anak memiliki hak kepemimpinan terbesar bila dalam sebuah keluarga memiliki 3 orang anak.

Itulah sebabnya otoritas di dalam gereja tidak datang melalui jumlah suara terbanyak, melainkan dari Firman Allah, yang mana kepemimpinan laki-laki terhadap perempuan sama dengan kepempinan Tuhan terhadap manusia. Selain itu, istri harus rela mengakui kepemimpinan suami mereka. "Karena suami adalah kepala isteri sama seperti Kristus adalah kepala jemaat. Dialah yang menyelamatkan tubuh.Karena itu sebagaimana jemaat tunduk kepada Kristus, demikian jugalah isteri kepada suami dalam segala sesuatu.

Paulus juga menunjukkan bahwa para penatua haruslah seorang suami, yaitu laki-laki. "Karena itu penilik jemaat haruslah seorang yang tak bercacat, suami dari satu isteri" (1 Timotius 3: 2). "Paulus tidak mengatakan bahwa semua laki-laki dapat menjadi uskup. Bahkan seperti di dalam Perjanjian Lama, tidak semua anak Harun bisa menjadi imam. Kedudukan tersebut selalu memiliki tempat yang terbatas. Pemimpin Kekristenan, Paulus berbicara tentang haruslah ia didapati 'tidak bersalah' dan sudah menikah, 'waspada, sadar, berperilaku baik, dan lain sebagainya. Ada daftar persyaratan yang panjang yang akhirnya menyisihkan sebagian besar pria dan menyisakan sedikit yang memenuhi syarat." Wanita bukanlah satu-satunya yang tidak memenuhi syarat untuk menjadi penatua dan pendeta, begitu juga sebagian besar laki-laki! Tentu saja, setiap orang Kristen, pria dan wanita, terpanggil untuk melayani di dalam beberapa bagian, tapi tidak semua bagian. "Dan Dialah yang memberikan baik rasul-rasul maupun nabi-nabi, baik pemberita-pemberita Injil maupun gembala-gembala dan pengajar-pengajar, untuk memperlengkapi orangorang kudus bagi pekerjaan pelayanan, bagi pembangunan tubuh Kristus".

Lalu apakah peran perempuan dalam gereja Kristus? Alkitab sangat jelas menyatakan bahwa perempuan seharusnya terlibat secara penuh di dalam pelayanan. Dan tentu saja, salah satu kelemahan terbesar di dalam gereja adalah kurangnya pelayanan perempuan yang benar-benar terfokus pada Kristus dan pertumbuhan di dalam Firman. Ditambah, di dalam Alkitab, perempuan ditunjukkan sebagai setara di dalam sifat pelayanan mereka. 
Seperti yang kita lihat, perempuan memiliki peran yang sangat penting dalam gereja Tuhan sepanjang zaman. Dan hal tersebut belum berubah. Namun walaupun laki-laki dan perempuan sama-sama melayani Tuhan dengan cara yang signifikan, kita seharusnya tidak menyimpulkan bahwa Allah bermaksud membuat pria dan wanita untuk berada dalam kaspasitas yang sama.

Namun hanya karena 1 Timotius 2:12 dengan tegas mengajarkan bahwa seorang wanita tidak untuk mengajarkan laki-laki, perempuan tetap bebas untuk mengajar di banyak cara lain. Bahkan, wanita diperintahkan untuk menjelaskan Injil kepada semua orang, termasuk orang-orang yang hilang (Kis 18:26). Dalam gereja, perempuan mungkin mengajar perempuan dan anak-anak. Bersama laki-laki di dalam gereja, perempuan harus mendiskusikan hal-hal spiritual dengan cara yang menerangkan tetapi tidak dengan menyuruh (menunjukkan kekuasaan). Ini tidak berarti bahwa laki-laki tidak dapat belajar dari perilaku wanita atau dari percakapannya dengan seorang wanita dan menerapkan apa yang mereka pelajari dalam hidupnya. Sebaliknya, artinya adalah bahwa tujuan wanita dalam berbicara dengan seorang pria tidak untuk menginstruksikan dia seperti yang seorang pemimpin lakukan. Tentu saja, pembatasan Paulus tentang perempuan dalam mengajar dan otoritasnya atas laki-laki telah ditantang dengan beberapa cara lain. Beberapa mengatakan bahwa kata-katanya dalam 1 Timotius 2:12, "Aku tidak menyarankan," adalah pernyataan pribadi, tapi bukan sesuatu untuk gereja pada umumnya.

Namun, hal ini dapat merusak otoritas kerasulan Paulus; ia sering berbicara sebagai orang pertama yang mengarahkan gereja (1 Timotius 2: 1, 8, 9). Beberapa orang yang lain bahkan berpendapat bahwa Paulus salah adanya, tetapi ini harus ditolak dengan alasan doktrin yang berlandaskan dari Alkitab (2 Timotius 3:16). Meskipun kita dapat menyimpulkan bahwa seorang wanita tidak boleh menjadi seorang pendeta atau penatua dalam gereja, adalah jelas bahwa wanita penting bagi gereja dan melakukan hal-hal yang penting di dalam gereja. Wanita yang memenuhi peran yang ditetapkan Tuhan bagi dirinya tidak kalah dengan cara apapun dengan seorang pria; melainkan dia akan bertindak sebagai seorang wanita yang saleh.

\section{E. Kesimpulan}


Manusia baru adalah manusia yang sudah dirubah sebagai orang yang mengerti pola ciptaan dan dapat hidup dengan kepatuhan terhadap Tuhan. Jadi Paulus tidak pernah menghapuskan tugas laki-laki dan perempuan. Tidak. Ia menjelaskan bahwa Kristus telah menghapuskan semua perbedaan yang berhubungan dengan nilai rohani: Masing-masing kita dibenarkan oleh iman dan sama-sama diberikan hak untuk menjadi anak-anak Allah. kita dapat menyimpulkan bahwa seorang wanita tidak boleh menjadi seorang pendeta atau penatua dalam gereja, adalah jelas bahwa wanita penting bagi gereja dan melakukan hal-hal yang penting di dalam gereja. Wanita yang memenuhi peran yang ditetapkan Tuhan bagi dirinya tidak kalah dengan cara apapun dengan seorang pria; melainkan dia akan bertindak sebagai seorang wanita yang saleh.

\section{F. Saran}

Kajian ini masih sangat jauh dari kata sempurna. Karena itu, perlu untuk disempurnakan lagi, untuk memperluas dan menambah wawasan mengenai pemahaman mengenai peran perempuan di dalam dalam alkitab, dengan lebih banyak membaca buku-buku referensi teologia dan jurnal-jurnal teologia yang membahas mengenai peran penting perempuan Kristen,dan hal itu tentu saja membuat kajian ini akan lebih sempurna. 


\section{Daftar Pustaka}

1. Amazing Facts Indonesia, "Peran Yang Tuhan Berikan Bagi Perempuan Dalam Pelayanan," https://amazingfacts.id/peran-tuhan-berikan-bagi-perempuan-pelayanan/ (31 Agustus 2016). 